\title{
Clinical and immunological characteristics of patients with undifferentiated connective tissue disease and dominating skin manifestation
}

\section{Charakterystyka kliniczna i immunologiczna pacjentów z niezróżnicowaną chorobą tkanki łącznej i dominującą manifestacją skórną}

Magdalena Celińska-Löwenhoff', Maciej Pastuszczak², Magdalena Stec-Polak², Katarzyna Tyrak², Anna Wojas-Pelc², Jacek Musiał'

\author{
'Professor Andrzej Szczeklik 2 ${ }^{\text {nd }}$ Department of Internal Diseases at the Jagiellonian University School of Medicine (Collegium \\ Medicum), Krakow, Poland \\ ${ }^{2}$ Dermatology Department at the Jagiellonian University School of Medicine (Collegium Medicum), Krakow, Poland \\ ${ }^{3}$ Dermatology Ward at Stefan Żeromski Specialist Hospital, Krakow, Poland
}

'Il Katedra Chorób Wewnętrznych im. Prof. Andrzeja Szczeklika Uniwersytetu Jagiellońskiego Collegium Medicum w Krakowie, Polska 2Katedra i Klinika Dermatologii Uniwersytetu Jagiellońskiego Collegium Medicum w Krakowie, Polska

${ }^{3}$ Oddział Dermatologii Szpitala Specjalistycznego im. Stefana Żeromskiego w Krakowie

\section{CORRESPONDING AUTHOR/} ADRES DO KORESPONDENCJI: dr n. med. Maciej Pastuszczak Katedra i Klinika Dermatologii Uniwersytet Jagielloński Collegium Medicum ul. Skawińska 8 31-066 Kraków, Polska tel.: +48 1243052 66, wew. 7416 e-mail: mpastuszczak@wp.pl

\begin{abstract}
Introduction. Undifferentiated connective tissue disease (UCTD) is characterized by presence of clinical and serological symptoms suggesting an autoaggressive systemic disease, while not meeting the criteria for diagnosing a defined entity. Over $50 \%$ of patients show skin lesions, which require dermatologic consultations.

Objective. To present clinical and immunological characteristics of patients with undifferentiated connective tissue disease.

Material and methods. Sixty patients were selected from all hospitalized at the Department of Allergy and Immunology and Department of Dermatology of the University Hospital in Krakow, Poland. The basis for selection was the diagnosis of "other overlap syndromes" (ICD-10 M35.1). All patients presented with symptoms suggesting connective tissue diseases and had circulating antinuclear antibodies.

Results. Ninety percent of the patients were women (median age of all group: 55 years). The most common skin and systemic symptoms as well as abnormalities in laboratory tests were the following: hypersensitivity to UV radiation (55\%), arthralgia (55\%), and moderate leukopenia (17\%). Subclinical pulmonary fibrosis was revealed in 12 out of $60(20 \%)$ patients. Forty-seven percent of the patients did not require systemic treatment. The other patients were most often administered glucocorticosteroids (43\%) and hydroxychloroquine (13\%). The statistical analysis showed dependence between the Raynaud's syndrome and a sixfold increase in risk of co-occurring disorders in gastrointestinal motility, and between symptoms of Sjögren's syndrome and a fivefold increase in chances for co-occurring pulmonary fibrosis $(p<0.05)$.

Conclusions. Undifferentiated connective tissue disease in most patients has a mild course and does not require systemic treatment. However, the disease is associated with a significant risk of progressing to
\end{abstract}


a defined connective tissue disease. When taking care of a patient with an undifferentiated connective tissue disease it is important to know the prognosis, the most common clinical symptoms and a possible co-occurrence of particular symptoms, what will direct further diagnostics and follow-up.

\section{STRESZCZENIE}

Wprowadzenie. Niezróżnicowana choroba tkanki łącznej charakteryzuje się obecnością klinicznych i serologicznych objawów świadczących o układowej chorobie $\mathrm{z}$ autoagresji, przy niespełnieniu kryteriów rozpoznania żadnej ze zdefiniowanych jednostek. Ponad $50 \%$ chorych ma zmiany skórne, które stanowią przyczynę konsultacji dermatologicznych.

Cel pracy. Przedstawienie charakterystyki klinicznej i immunologicznej pacjentów z niezróżnicowaną chorobą tkanki łącznej.

Materiał i metodyka. Spośród pacjentów hospitalizowanych z rozpoznaniem „inne zespoły nakładające się” (wg ICD-10 M35.1) w Klinice Alergii i Immunologii oraz Klinice Dermatologii Szpitala Uniwersyteckiego w Krakowie wyselekcjonowano i poddano analizie 60 chorych, u których stwierdzono obecność przeciwciał przeciwjądrowych, objawy świadczące o chorobie tkanki łącznej oraz zmiany skórne.

Wyniki. Kobiety stanowiły $90 \%$ chorych (mediana wieku całej grupy badanej: 55 lat). Najczęściej stwierdzanym objawem skórnym, objawem układowym i nieprawidłowością w badaniach laboratoryjnych były, odpowiednio: nadwrażliwość na promieniowanie UV (55\%), dolegliwości bólowe stawów (55\%) i umiarkowana leukopenia (17\%). Bezobjawowe włóknienie płuc wykazano u 12 (20\%) chorych spośród 60 poddanych analizie. Leczenia systemowego nie wymagało $47 \%$ chorych. U pozostałych pacjentów najczęściej stosowano ogólnie glikokortykosteroidy (43\%) i hydroksychlorochinę (13\%). W analizie statystycznej stwierdzono, że chorzy z objawem Raynauda mają 6-krotnie większe ryzyko współwystępowania zaburzeń motoryki przewodu pokarmowego, a u chorych z objawami zespołu suchości 5-krotnie zwiększa się ryzyko współistnienia włóknienia płuc $(p<0,05)$.

Wnioski. Niezróżnicowana choroba tkanki łącznej u większości chorych przebiega łagodnie i nie wymaga leczenia systemowego. Choroba wiąże się jednak $\mathrm{z}$ istotnym ryzykiem progresji do zdefiniowanej choroby tkanki łącznej. Wydaje się, że w opiece nad pacjentem z niezróżnicowaną chorobą tkanki łącznej niezwykle ważna jest znajomość rokowania, najczęstszych objawów klinicznych oraz współistnienia ze sobą poszczególnych symptomów, co pozwala odpowiednio ukierunkować dalszą diagnostykę i leczenie.

Key words: undifferentiated connective tissue disease, autoimmunology, clinical picture.

Słowa kluczowe: niezróżnicowana choroba tkanki łącznej, autoimmunologia, obraz kliniczny.

\section{INTRODUCTION}

Undifferentiated connective tissue disease (UCTD) is characterized by presence of clinical and serological symptoms suggesting an autoaggressive systemic disease. However, the patients do not meet

\section{WPROWADZENIE}

Niezróżnicowana choroba tkanki łącznej (undifferentiated connective tissue disease - UCTD) charakteryzuje się obecnością klinicznych i serologicznych objawów świadczących o układowej chorobie 
the criteria necessary to diagnoses a specific autoimmune disease, e.g. lupus erythematosus or systemic sclerosis [1]. Since 1980, when the term undifferentiated connective tissue disease was introduced for the first time, scope of knowledge regarding the clinical picture and, first and foremost, prognoses in this disease entity have been significantly broadened. For decades it has been believed that UCTD is a mild disease associated with a slight risk of internal organ damage. Yet, the newest research seems to confirm previous conclusions only in some parts. Indeed, the clinical course of UCTD is slow, and prognoses are better then in cases of other autoaggressive diseases [2]. Nevertheless, it is estimated that almost 30\% patients with UCTD may progress to a defined systemic autoimmune disease (most commonly lupus) $[3,4]$. Recent research indicates also an underestimated frequency of pulmonary fibrosis occurrence in UCTD [5].

Almost $60 \%$ of patients with UCTD has skin symptoms. Most often they include a non-specific discomfort such as hypersensitivity to UV radiation and non-characteristic erythematous lesions [5, 6]. Thus, most patients initiate a diagnostic and treatment process at the dermatologist's. Consequently, it is of the essence that dermatologists know the entire spectrum of UCTD's clinical picture, possible complications and scope of diagnostic tests necessary to regularly control patients with UCTD. Practitioners may be also interested in learning about existing relations between particular skin symptoms and a risk of organ lesions within the course of UCTD.

\section{OBJECTIVE}

The main aim of this paper is to present clinical and immunological characteristics of patients with UCTD and skin lesions. Furthermore, an analysis of relationships between chosen clinical and laboratory features was performed.

\section{MATERIAL AND METHODS}

In total, medical histories of 450 patients hospitalized in 2015-2017 at Allergy and Immunology Ward and Dermatology Ward at University Hospital in Krakow, Poland, were analysed. All these patients were diagnosed with ICD-10: M.35 - other systemic involvement of connective tissue, M35.1 - other overlap syndromes, M35.8 - other specified systemic involvement of connective tissue, and M35.9 - systemic involvement of connective tissue, unspecified. Further analysis included 110 patients who were found to have: present antinuclear antibodies titres of at least $1: 320$, and symptoms suggesting a connective tissue z autoagresji. Pacjenci nie spełniają jednak kryteriów koniecznych do rozpoznania konkretnej choroby o podłożu autoimmunologicznym, takiej jak toczeń rumieniowaty lub twardzina układowa [1]. Od 1980 r., kiedy po raz pierwszy wprowadzono termin niezróżnicowana choroba tkanki łącznej, istotnie poszerzyła się wiedza dotycząca obrazu klinicznego, a przede wszystkim rokowania w tej jednostce chorobowej [1]. Przez dziesięciolecia uważano, że UCTD jest łagodnym schorzeniem związanym $\mathrm{z}$ niewielkim ryzykiem uszkodzenia narządów wewnętrznych. Wydaje się jednak, że najnowsze badania tylko częściowo potwierdzają wcześniejsze ustalenia. Istotnie przebieg kliniczny UCTD jest powolny, a rokowanie lepsze niż $w$ innych chorobach $z$ autoagresji [2]. Szacuje się jednak, że niemal u 30\% pacjentów z UCTD choroba może się rozwijać aż do zdefiniowanej układowej choroby autoimmunologicznej (najczęściej tocznia) $[3,4]$. Ostatnie badania wskazują także na niedoszacowaną dotychczas częstość występowania włóknienia płuc w UCTD [5].

Niemal $60 \%$ pacjentów z UCTD ma objawy skórne. Najczęściej są to niespecyficzne dolegliwości, takie jak nadwrażliwość na promieniowanie UV i niecharakterystyczne zmiany rumieniowe [5, 6]. Większość pacjentów rozpoczyna proces diagnostyczny i leczniczy w gabinetach dermatologicznych. Niezwykle istotne jest, aby dermatolodzy znali spektrum obrazu klinicznego UCTD, możliwe powikłania i zakres badań diagnostycznych niezbędnych do regularnej kontroli pacjentów. Interesujące dla praktyków może być także poznanie zależności pomiędzy pewnymi objawami skórnymi a ryzykiem wystąpienia zmian narządowych w przebiegu UCTD.

\section{CEL PRACY}

Głównym celem niniejszej pracy było przedstawienie charakterystyki klinicznej i immunologicznej pacjentów z UCTD i zmianami skórnymi. Ponadto przeanalizowano zależności między wybranymi cechami klinicznymi i laboratoryjnymi.

\section{MATERIAŁ I METODYKA}

Łącznie przeanalizowano historie chorób 450 pacjentów hospitalizowanych w latach 2015-2017 w Klinice Alergii i Immunologii oraz Klinice Dermatologii Szpitala Uniwersyteckiego w Krakowie, u których ustalono rozpoznania wg ICD-10: M35 - inne układowe zajęcie tkanki łącznej, M35.1 - inne zespoły nakładające się, M35.8 - inne układowe zajęcie tkanki łącznej i M35.9 - nieokreślone układowe zajęcie tkanki łącznej. Do dalszej analizy włączono 110 pacjentów, u których stwierdzono przeciwciała przeciwjądrowe $\mathrm{w}$ mianie 
disease that failed to meet the criteria for a defined autoaggressive systemic disease in its totality [1]. In order to exclude a defined autoimmune systemic disease, patients' clinical and laboratory data were analysed with regard to meeting the criteria for diagnosing systemic lupus erythematosus (SLICC 2012) [7], systemic sclerosis (ACR/EULAR 2013) [8], rheumatoid arthritis (ACR/EULAR 2010) [9], and Sjögren's syndrome (ACR/EULAR 2016) [10]. Sixty patients with UCTD and skin lesions were selected for the final analysis.

Hypersensitivity to UV radiation was evaluated on the basis of phototests conducted according to the way described by Misiak-Gałązka and Wolska [11]. An erythema visible after 24 hours after the application of UVB radiation dose $\leq 0.047 \mathrm{~J} / \mathrm{cm}^{2}$ was considered as a positive result.

The approval of the Bioethical Commission (KBET/160/A) was obtained for the tests.

\section{Statistical analysis}

Obtained demographic, clinical and laboratory data was subsequently analysed by descriptive statistics' methods using GraphPad Prism 7.0 (GraphPad Software Inc., La Jolla, CA, USA). If not defined otherwise, results are presented as number and percentage. Quantitative and ordinal variables were compared using the Mann-Whitney $U$ test and Fisher's exact test accordingly. $P<0.05$ was considered to be statistically significant.

\section{RESULTS}

Data regarding 60 patients aged 25-81 (median: 55), in whom UCTD and skin lesions were confirmed, was analysed. Ninety percent of patients included in the study were female.

The most common skin manifestation was hypersensitivity to UV radiation (55\%), persistent erythema (51.7\%), and Raynaud's syndrome (50\%) (table 1).

Revealed systemic symptoms were dominated by joint pain (most often small hands and feet) and fatigue $(55 \%$ and $30 \%$ of the analysed patients respectively). Pulmonary fibrosis was confirmed in 12 out of 60 examined patients (20\%) (table 2). In every radiologically identified case of pulmonary fibrosis, lesions were not connected to significant abnormalities in lung functional tests and did not require an intensive immunosuppressive treatment. The analysed group did not include cases of pulmonary hypertension.

All patients were found to have antinuclear antibodies (ANA), with an average titre for the entire group of $1: 1280$. Most often ANA were characterized by granular fluorescence pattern (68.3\%) (table 3$)$. In almost $3 / 4$ of patients, immunoblotting method did not show specificity of detected antibodies. In co najmniej 1 : 320 oraz objawy świadczące o chorobie tkanki łącznej, ale w całokształcie niespełniające kryteriów zdefiniowanej układowej choroby $\mathrm{z}$ autoagresji [1]. W celu wykluczenia zdefiniowanej układowej choroby autoimmunologicznej dane kliniczne i laboratoryjne pacjentów przeanalizowano pod kątem spełnienia kryteriów rozpoznania tocznia układowego (SLICC 2012) [7], twardziny układowej (ACR/EULAR 2013) [8], reumatoidalnego zapalenia stawów (ACR/EULAR 2010) [9] i zespołu Sjögrena (ACR/EULAR 2016) [10]. Do końcowej analizy wyselekcjonowano 60 pacjentów z UCTD i zmianami skórnymi.

Nadwrażliwość na promieniowanie UV oceniono na podstawie prób świetlnych, które wykonywano w sposób opisany przez Misiak-Gałązkę i Wolską [11]. Za wynik pozytywny uznawano rumień widzialny po 24 godzinach przy zastosowaniu dawki promieniowania $\mathrm{UVB} \leq 0,047 \mathrm{~J} / \mathrm{cm}^{2}$.

Na wykonanie badań uzyskano zgodę Komisji Bioetycznej (KBET/160/A).

\section{Analiza statystyczna}

Uzyskane dane demograficzne, kliniczne i laboratoryjne poddano kolejno analizie metodami statystyki opisowej za pomocą programu GraphPad Prism 7.0 (GraphPad Software Inc., La Jolla, CA, USA). Jeśli nie zdefiniowano inaczej, wyniki przedstawiono jako liczebność i odsetek. Zmienne ilościowe i porządkowe porównano odpowiednio testem U Manna-Whitneya i testem Fishera. Za istotny statystycznie przyjęto poziom istotności $p<0,05$.

\section{WYNIKI}

Przeanalizowano dane 60 pacjentów w wieku 2581 lat (mediana: 55), u których stwierdzono UCTD i zmiany skórne. Kobiety stanowiły $90 \%$ chorych włączonych do badania.

Najczęstszymi manifestacjami skórnymi były nadwrażliwość na promieniowanie UV (55\%), utrwalony rumień twarzy $(51,7 \%)$ oraz objaw Raynauda (50\%) (tab. 1).

Spośród stwierdzonych objawów układowych przeważały bóle stawów (najczęściej małych stawów rąk i stóp) oraz uczucie ogólnego zmęczenia zgłaszane przez pacjenta (odpowiednio 55\% i 30\% poddanych analizie pacjentów). Włóknienie płuc wykazano u 12 (20\%) spośród 60 badanych chorych (tab. 2). W żadnym zidentyfikowanym radiologicznie przypadku włóknienia płuc zmiany nie wiązały się $\mathrm{z}$ istotnymi nieprawidłowościami w testach czynnościowych płuc i nie wymagały intensywnego leczenia immunosupresyjnego. W poddanej analizie grupie nie stwierdzono przypadków nadciśnienia płucnego.

U wszystkich pacjentów obecne były przeciwciała przeciwjądrowe (ANA), w średnim mianie dla 
remaining cases, anti-Ro $(20 \%)$ was the most often identified antibody. In $8 \%$ of patients, anti-double stranded DNA (anti-dsDNA) antibodies were found with a low titre $(<1: 40)$.

The most common abnormality in basic laboratory tests was moderate leukopenia $(17 \%$, leucocyte median: $\left.3.8 \mathrm{~K} / \mathrm{mm}^{3}\right)$, lymphopenia $(11.7 \%$, lymphocyte median: $0.81 \mathrm{~K} / \mathrm{mm}^{3}$ ), and thrombocytopenia $(11.7 \%$, blood platelet median: $106 \mathrm{~K} / \mathrm{mm}^{3}$ ) (table 3).

The highest percentage of the analysed patients was characterized by occurrence of two skin symptoms, three systemic symptoms and one ANA fluorescence pattern $(33.3 \%, 43.3 \%$, and $56.7 \%$ respectively) (table 4).

In patients with hypersensitivity to UV radiation, fatigue co-occurred significantly more often $(p<$ $0.001)$. Then, patients suffering from Raynaud's syndrome were characterized by a sixfold higher risk of occurrence of gastrointestinal motility disorders $(p<0.05)$, and a twelvefold higher chance of revealing thrombocytopenia $(p<0.01)$. ANA granular fluorescence pattern characterized patients with facial erythema significantly more often $(p<0.05)$, whereas anti-Ro antibodies were statistically significant in patients with joint pain and symptoms of Sjögren's syndrome $(p<0.05)$. Interestingly, patients with symptoms of Sjögren's syndrome exhibited slightly

Table I. Characteristics of skin lesions in patients with undifferentiated connective tissue disease $(n=60)$

Tabela I. Charakterystyka zmian skórnych u pacjentów z niezróżnicowaną chorobą tkanki łącznej $(n=60)$

\begin{tabular}{|c|c|}
\hline Lesion/Zmiana & $\begin{array}{l}\text { Number and percentage } \\
\text { of patients with particular } \\
\text { skin lesions/ } \\
\text { Liczba i odsetek pacjentów } \\
\text { z poszczególnymi } \\
\text { zmianami skórnymi, } n(\%)\end{array}$ \\
\hline $\begin{array}{l}\text { Hypersensitivity to UV } \\
\text { radiation/Nadwrażliwość na } \\
\text { promieniowanie UV }\end{array}$ & $33(55)$ \\
\hline $\begin{array}{l}\text { Persistent facial erythema/ } \\
\text { Utrwalony rumień twarzy }\end{array}$ & $3 \mid(5 \mid .7)$ \\
\hline $\begin{array}{l}\text { Raynaud's syndrome/ } \\
\text { Objaw Raynauda }\end{array}$ & $30(50)$ \\
\hline $\begin{array}{l}\text { Erythema of the palmar surface/ } \\
\text { Rumień powierzchni dłoniowej } \\
\text { ręki }\end{array}$ & $23(38.3)$ \\
\hline $\begin{array}{l}\text { Thickened finger skin/ } \\
\text { Stwardnienia skóry palców rąk }\end{array}$ & $14(23.3)$ \\
\hline $\begin{array}{l}\text { Finger oedema/ } \\
\text { Obrzęki palców rąk }\end{array}$ & $13(2 \mid .7)$ \\
\hline Livedo reticularis/Livedo reticularis & $8(13.3)$ \\
\hline $\begin{array}{l}\text { Diffuse telogen alopecia/ } \\
\text { Rozlane łysienie telogenowe }\end{array}$ & $7(11.7)$ \\
\hline $\begin{array}{l}\text { Thinning of vermillion border/ } \\
\text { Ścieńczenie czerwieni wargowej }\end{array}$ & $5(8.3)$ \\
\hline
\end{tabular}

całej grupy wynoszącym 1 : 1280. Najczęściej ANA charakteryzowały się ziarnistym typem świecenia $(68,3 \%)$ (tab. 3). U niemal 3/4 chorych metodą immunoblotu nie wykazano specyficzności wykrytych przeciwciał. W pozostałych przypadkach najczęściej identyfikowano przeciwciała anty-Ro (20\%). U 8\% chorych stwierdzono obecność w niskim mianie $(<1: 40)$ przeciwciał przeciwko dwuniciowemu DNA.

Najczęściej stwierdzaną nieprawidłowością w podstawowych badaniach laboratoryjnych była umiarkowana leukopenia $(17 \%$, mediana leukocytów 3,8 tys. $\left./ \mathrm{mm}^{3}\right)$, limfopenia $(11,7 \%$, mediana limfocytów 0,81 tys. $\left./ \mathrm{mm}^{3}\right)$ i małopłytkowość $(11,7 \%$, mediana płytek krwi 106 tys./ $\mathrm{mm}^{3}$ ) (tab. 3).

Dwa objawy skórne, trzy objawy systemowe i jeden typ świecenia przeciwciał przeciwjądrowych były obecne u największego odsetka pacjentów poddanych analizie (odpowiednio: 33,3\%, 43,3\% i 56,7\%) (tab. 4).

U pacjentów z nadwrażliwością na promieniowanie UV istotnie częściej współwystępowało zmęczenie $(p<0,001)$. Natomiast chorzy z objawem Raynauda mieli 6-krotnie większe ryzyko występowania zaburzeń motoryki przewodu pokarmowego $(p<0,05)$ i 12-krotnie większe prawdopodobieństwo stwierdzenia małopłytkowości $(p<0,01)$. Ziarnisty typ świecenia ANA istotnie częściej charakteryzował pacjentów z rumieniem twarzy $(p<0,05)$, natomiast przeciwciała anty-Ro statystycznie istotnie częściej identyfikowano $\mathrm{u}$ pacjentów $\mathrm{z}$ dolegliwościami bólowymi stawów i objawami zespołu suchości $(p<0,05)$.

Table 2. Characteristics of systemic symptoms in patients with undifferentiated connective tissue disease $(n=60)$

Tabela 2. Charakterystyka objawów układowych u pacjentów z niezróżnicowaną chorobą tkanki łącznej i zmianami skórnymi $(n=60)$

\begin{tabular}{|c|c|}
\hline Symptom/Objaw & $\begin{array}{c}\text { Number and percentage } \\
\text { of patients with particular } \\
\text { systemic symptoms/ } \\
\text { Liczba i odsetek pacjentów } \\
\text { z poszczególnymi objawami } \\
\text { układowymi, } n(\%)\end{array}$ \\
\hline Joint pain/Bóle stawów & $33(55)$ \\
\hline Fatigue/Zmęczenie & $18(30)$ \\
\hline $\begin{array}{l}\text { Pulmonary fibrosis/ } \\
\text { Włóknienie płuc }\end{array}$ & $12(20)$ \\
\hline $\begin{array}{l}\text { Esophageal motility disorder/ } \\
\text { Zaburzenia motoryki przełyku }\end{array}$ & II (I8.3) \\
\hline $\begin{array}{l}\text { Symptoms of Sjögren's } \\
\text { syndrome/Objawy zespołu } \\
\text { Sjogrena }\end{array}$ & $8(13.3)$ \\
\hline $\begin{array}{l}\text { Myasthenia/Osłabienie siły } \\
\text { mięśniowej }\end{array}$ & $7(\mid 1.7)$ \\
\hline Muscle pain/Bóle mięśni & $5(8.3)$ \\
\hline $\begin{array}{l}\text { Recurrent oral ulcers/ } \\
\text { Nawracające owrzodzenia } \\
\text { w jamie ustnej }\end{array}$ & I ( 1.7$)$ \\
\hline Arthritis/Zapalenie stawów & I ( 1.7$)$ \\
\hline
\end{tabular}


over fivefold higher risk of co-occurring pulmonary fibrosis $(p<0.05)$, and sevenfold higher risk of co-occurring lymphopenia $(p<0.04)$ (table 5).

Further statistical analysis showed a significant dependence between occurrence of pulmonary fibrosis as well as gastrointestinal motility disorders, and a higher number of systemic symptoms $(p<0.001)$. Interestingly, a similar relationship between a higher number of ANA fluorescence patterns and a higher number of skin symptoms was not noted $(p>0.05)$.

Forty-seven percent of patients with UCTD and skin lesions did not require systemic therapies. The others were most often administered general drugs such as glucocorticosteroids $(43.3 \%)$, then hydroxychloroquine $(13.3 \%)$, methotrexate $(8.3 \%)$, and cyclophosphamide $(5 \%)$. Fifteen percent of patients required combination therapy - combination of glu-
Ponadto pacjenci z objawami zespołu suchości mieli nieco ponad 5-krotnie większe ryzyko współistnienia włóknienia płuc $(p<0,05)$ i 7-krotnie większe ryzyko wystąpienia limfopenii $(p<0,04)$ (tab. 5).

W dalszej analizie statystycznej stwierdzono istotną zależność między występowaniem włóknienia płuc i zaburzeń motoryki przewodu pokarmowego a większą liczbą objawów systemowych $(p<0,001)$. Podobnego związku nie odnotowano między większą liczbą typów świecenia przeciwciał przeciwjądrowych i większą liczbą objawów skórnych $(p>0,05)$.

Terapii ogólnej nie wymagało $47 \%$ pacjentów z UCTD i zmianami skórnymi. U pozostałych najczęściej stosowanymi ogólnie lekami były glikokortykosteroidy $(43,3 \%)$, następnie: hydroksychlorochina $(13,3 \%)$, metotreksat $(8,3 \%)$ i cyklofosfamid (5\%). Piętnaście procent chorych wymagało terapii skojarzonej - najczęściej stosowano połączenie glikokortykosteroidów

Table 3. Characteristics of chosen laboratory and immunological parameters in patients with undifferentiated connective tissue disease and skin lesions

Tabela 3. Charakterystyka wybranych parametrów laboratoryjnych i immunologicznych u pacjentów z niezróżnicowaną chorobą tkanki łącznej i zmianami skórnymi

\begin{tabular}{|c|c|}
\hline Parameter/Parametr & Value/Wartość \\
\hline ANA presence/Obecność ANA, $n$ (\%): & $60(100)$ \\
\hline granular fluorescence pattern/o typie świecenia ziarnistym & $41(68.3)$ \\
\hline homogenous fluorescence pattern/o typie świecenia homogennym & $11(18.3)$ \\
\hline cytoplasmic fluorescence pattern/o typie świecenia cytoplazmatycznym & $13(21.7)$ \\
\hline spindle apparatus fluorescence pattern/o typie świecenia wrzeciona podziałowego & $3(5)$ \\
\hline centromere fluorescence pattern/o typie świecenia centromerowym & $5(8.3)$ \\
\hline mitochondrial fluorescence pattern/o typie świecenia mitochondrialnym & I (I.7) \\
\hline nuclear dots fluorescence pattern/o typie świecenia nuclear dots & $3(5)$ \\
\hline nucleolar fluorescence pattern/o typie świecenia jąderkowym & $6(10)$ \\
\hline \multicolumn{2}{|l|}{ ANA titer/Miano ANA (min.-max.): } \\
\hline granular fluorescence pattern/o typie świecenia ziarnistym & $1280(160-20480)$ \\
\hline homogenous fluorescence pattern/o typie świecenia homogennym & $1280(320-10240)$ \\
\hline cytoplasmic fluorescence pattern/o typie świecenia cytoplazmatycznym & $1280(160-5120)$ \\
\hline spindle apparatus fluorescence pattern/o typie świecenia wrzeciona podziałowego & $5120(2560-20480)$ \\
\hline centromere fluorescence pattern/o typie świecenia centromerowym & $20480(10240-20480)$ \\
\hline mitochondrial fluorescence pattern/o typie świecenia mitochondrialnym & 20480 \\
\hline nuclear dots fluorescence pattern/o typie świecenia nuclear dots & $5120(|60-5| 20)$ \\
\hline nucleolar fluorescence pattern/o typie świecenia jąderkowym & $5120(640-20480)$ \\
\hline Presence of anti-dsDNA antibodies/Obecność przeciwciał anty-dsDNA, $n$ (\%) & $5(8.3)$ \\
\hline Presence of anti-Ro antibodies/Obecność przeciwciał anty-Ro, $n$ (\%) & $12(20)$ \\
\hline Presence of anti-La antibodies/Obecność przeciwciał anty-La, $n$ (\%) & $3(5)$ \\
\hline $\begin{array}{l}\text { Decrease in complement component C3 concentration }(<0.9 \mathrm{~g} / \mathrm{l}) / Z \text { mniejszenie stężenia składowej C3 } \\
\text { dopełniacza }(<0,9 \mathrm{~g} /), n(\%)\end{array}$ & $9(15)$ \\
\hline $\begin{array}{l}\text { Decrease in complement component C4 concentration }(<0.1 \mathrm{~g} / \mathrm{l}) / Z \text { mniejszenie stężenia składowej C4 } \\
\text { dopełniacza }(<0, \mathrm{I} / \mathrm{g}), n(\%)\end{array}$ & $8(13.3)$ \\
\hline Decrease in complement concentration C3 and C4/Zmniejszenie stężenia składowej C3 i C4 dopełniacza, n (\%) & $4(6.7)$ \\
\hline Leukopenia $\left(<4 \mathrm{~K} / \mathrm{mm}^{3}\right) /$ Leukopenia $\left(<4\right.$ tys. $\left./ \mathrm{mm}^{3}\right), n(\%)$ & $10(16.7)$ \\
\hline Lymphopenia $\left(<\right.$ I K/mm³)/Limfopenia $\left(<\right.$ I tys. $\left./ \mathrm{mm}^{3}\right), n(\%)$ & $7(\mid 1.7)$ \\
\hline Thrombocytopenia $\left(<150 \mathrm{~K} / \mathrm{mm}^{3}\right) /$ Małopłytkowość $\left(<150\right.$ tys. $\left./ \mathrm{mm}^{3}\right), n(\%)$ & $10(16.7)$ \\
\hline
\end{tabular}


Table 4. Percentage of patients $(n=60)$ with a particular number of skin and systemic symptoms, as well as found ANA fluorescence patterns

Tabela 4. Odsetek pacjentów $(n=60)$ z poszczególnymi liczbami objawów skórnych, ogólnych i stwierdzanych typów świecenia przeciwciał przeciwjądrowych

\begin{tabular}{|c|c|}
\hline Parameter/Parametr & $n(\%)$ \\
\hline \multicolumn{2}{|c|}{ Number of skin symptoms/Liczba objawów skórnych: } \\
\hline 1 & $18(30)$ \\
\hline$\overline{2}$ & $20(33.3)$ \\
\hline 3 & $15(25)$ \\
\hline 4 & $7(\mid 1.7)$ \\
\hline \multicolumn{2}{|c|}{ Number of systemic symptoms/Liczba objawów ogólnych: } \\
\hline 1 & $9(15)$ \\
\hline 2 & $20(33.3)$ \\
\hline 3 & $26(43.3)$ \\
\hline 4 & $3(5)$ \\
\hline 5 & $2(3.3)$ \\
\hline \multicolumn{2}{|c|}{$\begin{array}{l}\text { Number of found ANA fluorescence patterns/ } \\
\text { Liczba stwierdzanych typów świecenia ANA: }\end{array}$} \\
\hline I & $34(56.7)$ \\
\hline 2 & $13(21.7)$ \\
\hline 3 & $11(18.3)$ \\
\hline 4 & $2(3.3)$ \\
\hline
\end{tabular}

Table 5. Significant correlations between clinical, immunological, and laboratory parameters in patients with undifferentiated connective tissue disease and skin lesions

Tabela 5. Istotne korelacje parametrów klinicznych, immunologicznych i laboratoryjnych u pacjentów z niezróżnicowaną chorobą tkanki łącznej i zmianami skórnymi

\begin{tabular}{|c|c|c|c|}
\hline Parameter/Parametr & Parameter/Parametr & OR $(95 \% \mathrm{Cl})$ & $P$-value/Wartość $P$ \\
\hline $\begin{array}{l}\text { Hypersensitivity to UV radiation/ } \\
\text { Nadwrażliwość na promieniowanie UV }\end{array}$ & $\begin{array}{c}\text { Fatigue/Zmęczenie } \\
\text { Gastrointestinal motility disorders/ } \\
\text { Zaburzenia motoryki przewodu pokarmowego }\end{array}$ & $\begin{array}{l}10.4(2.5-47.3) \\
0.05(0.003-0.9)\end{array}$ & $\begin{array}{c}0.0007 \\
0.003\end{array}$ \\
\hline Facial erythema/Rumień twarzy & $\begin{array}{c}\text { Granular ANA/ANA ziarniste } \\
\text { Decrease in complement concentration C3/ } \\
\text { Zmniejszone stężenie składowej C3 dopełnicza }\end{array}$ & $\begin{array}{l}4.2(1.3-14.1) \\
0.1(0.02-0.7)\end{array}$ & $\begin{array}{l}0.02 \\
0.01\end{array}$ \\
\hline Raynaud's syndrome/Objaw Raynauda & $\begin{array}{c}\text { Thrombocytopenia/Małopłytkowość } \\
\text { Gastrointestinal motility disorders/ } \\
\text { Zaburzenia motoryki przewodu pokarmowego }\end{array}$ & $\begin{array}{c}12.4(1.5-105.8) \\
6.0(1.2-30.7)\end{array}$ & $\begin{array}{c}0.006 \\
0.02\end{array}$ \\
\hline Muscle pain/Bóle mięśni & Centromere ANA/ANA centromerowe & $14.3(1.4-140.6)$ & 0.04 \\
\hline Joint pain/Bóle stawów & Anti-Ro/Anty-Ro & $5.4(1.1-27.5)$ & 0.03 \\
\hline $\begin{array}{l}\text { Symptoms of Sjögren's syndrome/ } \\
\text { Objawy zespołu Sjogrena }\end{array}$ & $\begin{array}{c}\text { Anti-Ro/Anty-Ro } \\
\text { Pulmonary fibrosis/Włóknienie płuc } \\
\text { Lymphopenia/Limfopenia }\end{array}$ & $\begin{array}{l}5.5(1.1-26.6) \\
5.2(1.8-28.3) \\
7.2(1.2-41.8)\end{array}$ & $\begin{array}{l}0.04 \\
0.03 \\
0.04\end{array}$ \\
\hline
\end{tabular}

cocorticosteroids and hydroxychloroquine was most often used. In patients with persistent facial erythema and joint pain, hydroxychloroquine was more often used in treatment than other drugs, what was statistically significant $(p<0.05)$.

\section{DISCUSSION}

Results of the study indicate that over $50 \%$ of patients with UCTD has skin lesions, which make patients seek medical help in the first place. In the z hydroksychlorochiną. U pacjentów z utrwalonym rumieniem twarzy i dolegliwościami bólowymi stawów statystycznie istotnie częściej stosowano w leczeniu hydroksychlorochinę niż pozostałe leki $(p<0,05)$.

\section{OMÓWIENIE}

Wyniki niniejszego badania wskazują, że ponad $50 \%$ pacjentów z UCTD ma zmiany skórne, które przede wszystkim skłaniają do poszukiwania pomocy lekarskiej. W analizowanej grupie najczęściej 
analysed group, hypersensitivity to UV radiation, facial erythema and Raynaud's syndrome were most commonly noted. This data corresponds with the data from references [12-14]. According to the literature data the most common systemic symptom in UCTD is joint pain without signs of inflammation, what was also confirmed in the analysed patient cohort [1].

In $20 \%$ of patients clinically silent pulmonary fibrosis was revealed that was not associated with abnormalities in functional lung tests. In other similar studies, frequency of pulmonary fibrosis co-occurrence in UCTD is estimated at about $8-10 \%[5,6,12]$. A higher percentage observed by us may be partly explained by an increased, in comparison with other studies, diagnostic vigilance evincing itself in the fact that we performed a routine high-resolution computed tomography in almost every patient.

So far, immunological predictive factors of occurrence of concrete skin and systemic symptoms in UCTD have not been identified. However, in statistical analysis of clinical symptoms we showed an interesting relationship between occurrence of Sjögren's syndrome symptoms and a slightly more than fivefold increase in risk of co-occurring pulmonary fibrosis that has not been described in literature so far. This observation may be important in a daily clinical practice.

This was not a prospective work, but multiannual observations of patients with UCTD indicate that almost $70 \%$ of them maintain an undifferentiated clinical and immunological phenotype. Approximately $30 \%$ of patients progresses to a defined (differentiated) connective tissue disease, most often systemic lupus erythematosus $[3,6,12,13]$. Factors, which were defined as the ones associated with an increased risk of progression to systemic lupus erythematosus, include hypersensitivity to UV radiation, alopecia, and Raynaud's syndrome $[5,6,15]$. This knowledge may be especially useful for dermatologists in planning care over patients with UCTD.

\section{CONCLUSIONS}

Undifferentiated connective tissue disease is characterized by diverse skin and systemic symptomatology. However, the disease has a mild course and the ailments are mild in severity and rarely require an immunosuppressive treatment. More than a half of patients is characterized by skin manifestations; hence, it is of the essence that dermatologists are familiar with the clinical picture, immunological profile, and prognoses in UCTD. An early and proper diagnosis is very important in clinical practice. It allows for planning a control regimen and avoiding an unnecessary and aggressive treatment. Knowing stwierdzano nadwrażliwość na promieniowanie UV, rumień twarzy oraz objaw Raynauda, co koresponduje $z$ danymi z piśmiennictwa [12-14]. Według danych z piśmiennictwa najczęstszym objawem ogólnym UCTD są dolegliwości bólowe stawów bez cech zapalenia, co także zostało potwierdzone w analizowanej kohorcie pacjentów [1].

U $20 \%$ pacjentów stwierdzono bezobjawowe włóknienie płuc, które nie było związane z nieprawidłowościami w testach czynnościowych płuc. W innych podobnych badaniach częstość współistnienia włóknienia płuc w UCTD szacuje się na ok. 8-10\% $[5,6,12]$. Obserwowany przez autorów niniejszej pracy wyższy odsetek może być częściowo wytłumaczony większą w porównaniu z innymi badaniami czujnością diagnostyczną, która przejawiała się tym, że niemal u wszystkich pacjentów rutynowo wykonywano tomografię komputerową o wysokiej rozdzielczości.

Nie udało się dotychczas zidentyfikować immunologicznych czynników predykcyjnych wystąpienia konkretnych objawów skórnych i ogólnych w UCTD. W analizie statystycznej korelacji objawów klinicznych wykazano jednak dotychczas nieopisywaną w piśmiennictwie, interesującą zależność między występowaniem objawów zespołu suchości a nieco ponad 5-krotnie wyższym ryzykiem współistnienia włóknienia płuc. Obserwacja ta może mieć duże znaczenie w codziennej praktyce klinicznej.

Niniejsza praca nie miała charakteru prospektywnego, ale wieloletnie obserwacje pacjentów z UCTD wskazują, że u niemal 70\% z nich utrzymuje się niezróżnicowany fenotyp kliniczny i immunologiczny. U ok. 30\% pacjentów choroba rozwija się do zdefiniowanej (zróżnicowanej) choroby tkanki łącznej, najczęściej tocznia układowego [3, 6, 12, 13]. Czynnikami, które zidentyfikowano jako związane z większym ryzykiem progresji do tocznia rumieniowatego układowego, są m.in. nadwrażliwość na promieniowanie UV, łysienie i objaw Raynauda [5, 6, 15]. Wiedza ta może być szczególnie przydatna dermatologom w planowaniu opieki nad pacjentami z UCTD.

\section{WNIOSKI}

Niezróżnicowana choroba tkanki łącznej charakteryzuje się różnorodną symptomatologią skórną i systemową. Schorzenie przebiega jednak łagodnie, a dolegliwości najczęściej są miernie nasilone i rzadko wymagają leczenia immunosupresyjnego. U ponad połowy pacjentów występuje manifestacja skórna, dlatego wydaje się bardzo istotne, aby dermatolodzy poznali obraz kliniczny, profil immunologiczny oraz rokowanie w UCTD. Wczesne i prawidłowe ustalenie rozpoznania jest niezwykle ważne w praktyce klinicznej. Umożliwia zaplanowanie schematu kontroli i uniknięcie niepotrzebnego, agresywnego leczenia. 
a natural course of the disease, it is possible to explain to a patient his/her prognoses, what increases his/ her psychological well-being.

\section{CONFLICT OF INTEREST}

The authors declare no conflict of interest.
Dzięki znajomości naturalnego przebiegu schorzenia można także przedstawić choremu rokowanie, co znacznie poprawia jego komfort psychiczny.

\section{KONFLIKT INTERESÓW}

Autorzy nie zgłaszają konfliktu interesów.

\section{References}

\section{Piśmiennictwo}

1. Mosca M., Neri R., Bombardieri S.: Undifferentiated connective tissue disease: a review of the literature and a proposal for preliminary classification criteria. Clin Exp Rheumatol 1999, 17, 615-620.

2. Mosca M., Tani C., Talarico R., Bombardieri S.: Undifferentiated connective tissue disease (UCTD): simplified systemic autoimmune diseases. Autoimm Rev 2011, 10, 256-258.

3. Danieli M.G., Fraticelli P., Franceschini F., Cattaneo R., Farsi A., Passaleva A., et al.: Five-year follow-up of 165 Italian patients with undifferentiated connective tissue diseases. Clin Exp Rheumatol 1999, 17, 585-591.

4. Danieli M.G., Fraticelli P., Salvi A., Gabrielli A., Danieli G.: Undifferentiated connective tissue disease: natural history and evolution into definite CTD assessed in 84 patients initially diagnosed as early UCTD. Clin Rheumatol 1998, 17, 195-201.

5. Vaz C.C., Couto M., Medeiros D., Miranda L., Costa J., Nero P., et al.: Undifferentiated connective tissue disease: a seven-center cross-sectional study of 184 patients. Clin Rheumatol 2009, 28, 915-921.

6. Guerrero L.F., Rueda J.C., Arciniegas R., Rueda J.M.: Undifferentiated connective tissue disease in a rheumatology center in Cali, Colombia: clinical features of 94 patients followed for a year. Rheumatol Int 2013, 33, 1085-1088.

7. Petri M., Orbai A.M., Alarcon G.S., Gordon C., Merrill J.T., Fortin P.R., et al.: Derivation and validation of systemic lupus international collaborating clinics classification criteria for systemic lupus erythematosus. Arthritis Rheum 2012, 64, 2677-2686.

8. van den Hoogen F., Khanna D., Fransen J., Johnson S.R., Baron M., Tyndall A., et al.: Classification criteria for systemic sclerosis: an ACR-EULAR collaborative initiative. Arthritis Rheum 2013, 65, 2737-2747.

9. Aletaha D., Neogi T., Silman A.J., Funovits J., Felson D.T., Bingham C.O., et al.: 2010 rheumatoid arthritis classification criteria. An Amercian College of Rheumatology/European League Against Rheumatism Collaborative Initiative. Arthritis Rheum 2010, 62, 2569-2581.

10. Shiboski C.H., Shiboski S.C., Seror R., Criswell L.A., Labetoulle M., Lietman T.M., et al.: 2016 American College of Rheumatology/European League Against Rheumatism classification criteria for primary Sjoegren's syndrome: a consensus and data-driven methodology involving three international patients cohorts. Arthritis Rheum 2017, 69, 35-45.

11. Misiak-Gałązka M., Wolska H.: Ocena nadwrażliwości na światło w oparciu o próby świetlne u pacjentów z trądzikiem różowatym - analiza retrospektywna. Przegl Dermatol 2012, 99, 595-599.

12. Bodolay E., Csiki Z., Szekanecz Z., Ben T., Kiss E., Zeher M., et al.: Five-year follow-up of 665 Hungarian patients with undifferentiated connective tissue disease. Clin Exp Rheumatol 2003, 21, 313-320.

13. Mosca M., Tani C., Carli L., Della Rossa A., Talarico R., Baldini C., et al.: Analysis of the evolution of UCTD to defined CTD after a long-term follow-up. Clin Exp Rheumatol 2013, 31, 471.

14. Górska K., Szczerkowska-Dobosz A., Purzycka-Bohdan D., Stawczyk-Macieja M., Wierzba K., Nowicki R.J.: Objaw Raynauda jako problem interdyscyplinarny. Przegl Dermatol 2017, 104, 499-508.

15. Vila L.M., Mayor A.M., Valentin A.H., Garcia-Soberal M., Vila S.: Clinical outcome and predictors of disease evolution in patients with incomplete lupus erythematosus. Lupus 2000, 9, 110-115.

Received: 13.07 .2018

Accepted: 21.10.2018

Otrzymano: 13.07.2018 r.

Zaakceptowano: $21.10 .2018 \mathrm{r}$.

How to cite this article

Celińska-Löwenhoff M., Pastuszczak M., Stec-Polak M., Tyrak K., Wojas-Pelc A., Musiał J.: Clinical and immunological characteristics of patients with undifferentiated connective tissue disease and dominating skin manifestation. Dermatol Rev/Przegl Dermatol 2018, 105, 701-709. DOI: https:// doi.org/10.5114/dr.2018.80838. 